\title{
Interdepartmental conflict in large enterprises in South Africa: a survey
}

\author{
B.J. Bloch \\ Economics Department, University of the Witwatersrand, 1 Jan Smuts Avenue, Johannesburg, 2000 Republic of South Africa
}

Received 15 October 1986

\begin{abstract}
Managerial literature has always tended to underrate the significance of the horizontal or lateral dimension of organizations. The rationale for this paper is the increasing importance of lateral interdepartmental relationships as business enterprises increase in size and complexity. The aim of this investigation is to determine the extent to which interdepartmental conflict prevails, and the nature of the causes thereof, in large enterprises in South Africa. The investigation was conducted by means of a mail survey of manufacturing enterprises with in excess of 300 employees. A questionnaire composed of 24 multiple-choice items was sent to 900 manufacturing enterprises. A total of 282 usable responses was obtained. Responses indicate that enterprises in the sample generally experience moderate to high levels of interdepartmental conflict. The results indicate that the kevel of interdepartmental conflict does not differ statistically with respect to size of enterprise, geographic location or the nature of the responding department. The breakdown of responses suggests that production and marketing departments play a dominant role in the interdepartmental scenario, with finance and persomel taking a scoondary role.
\end{abstract}

\begin{abstract}
In die bestuursliteratuur is die horisontale of sydelingse dimensie ven bestuur nog altyd geringgeskat. Soos ondememings groter en meer kompleks word, word sydelingse tussendepartementele skakeling al hoe belangriker. Die doelwit van hierdie ondersoek is om vas te stel in hoe 'n mate tussendepartementele konflik in groot Suid-Afrikaanse ondernemings aanwesig is, watter vorm dit aaneeem en wat dit veroorsaak. Die ondersoek bestaan uit 'n vraelys, bestaande uit 24 meervoudige keusevrse wat aan vervaardigingsondernemings met meer as 300 werknemers in diens gepos is. Uit 'n totaal van 900 is daar 282 bruikbare antwoorde terugontvang. Hieruit is vasgestel dat ondernemings cor die algemeen matige tot hoz tussendepartementele konflik ondervind. Geen statisties beduidende verwantskap tussen die mate van konflik en ondememingsgrootte, geografiese ligging en die aard van die departement waarin 'n respondent werksaam is, het uit die ondersoek geblyk nie. Dit wil voorkom woof produksie- en bemarkingsdepartemente die belangrikste rol in die tussendepartementele skakeling speel terwyl finansiele en personeeldepartemente minder belangrik is.
\end{abstract}

\section{Problem definition}

There are trends in industry which indicate that interdepartmental conflict is becoming a more relevant factor in the quest for efficiency and higher productivity. The increasing size of enterprises leads to larger, more autonomous departments and more activity across departmental boundaries. As the complexity of modern enterprises increases, so does the need to understand the full range of impact of any action. The escalation of managerial specialization should be accompanied by the development and expansion of knowledge which links together and integrates the major specialist disciplines of human resources (personnel) management, finance, production and marketing. According to Brown (1982:15) 'if you don't manage interface conflicts, they will manage you'. The problem of conflict in enterprises is compounded by the rate of social and technological change affecting the business environment. Change is invariably associated with conflict as old patterns of behaviour and thinking become obsolete and new responses and modus operandi must be introduced and accepted. This reduces the clarity and definition of authority, responsibility and appropriate behaviour between departments. All the above factors increase the need to relate to and deal with interdepartmental conflict.

Despite the increasing importance of interdepartmental or lateral relations, there is an overemphasis in managerial theory (and as a result inevitably in practice), on the vertical dimension of organizations. This vertical dimension refers to relationships within rather than between such departments as personnel, finance, production and marketing. Managerial literature reflects a preoccupation with the problems of leadership, authority, control, and the proliferation of skills that relate to the execution of some specialist activity. The horizontal dimension of management, which refers essentially to interdepartmental relations, is not given adequate treatment. Googe (1978: 475$)$ pointed to the fact that in the late 1950's and early 1960 's there was a reasonable degree of interest in intergroup relations, but since then, 'a seemingly abrupt decrease of interest seems to have left us with an incomplete and underdeveloped perspective of intergroup relations'. Writing even more recently, Brown (1982: 72) commented that 'emphasis on interfaces as the centre of attention is uncommon, though not unprecedented'.

\section{Literature survey}

The research related to interdepartmental conflict derives from two related but distinct sources; that which in the first instance refers to business enterprises, and that which deals with groups outside the business world, namely psychological and sociological research on small groups. Research on interdepartmental relationships is limited, but intergroup research is more prolific and the principles derived in this field are not far removed from the interdepartmental scenario. This literature survey is based primarily on business-related writing on interdepartmental relationships. The research projects are presented in chronological order within specific themes. For a more general theoretical analysis of interdepartmental conflict, see Bloch (1985).

\section{General intergroup and interdepartmental research}

Intergroup research first received serious attention in the early sixties by such writers as Blake \& Mouton (1961). 
They found that a cooperative goal could do much to alleviate the negative effects of a win/lose intergroup situation. Pondy's paper (1964) was based on field studies of capital budgeting practices in large manufacturing corporations. He drew attention to subgroup (departmental) loyalties which he found to have a substantial impact on the relationship between departments. Kahn, Wolfe, Quinn, Snoek and Rosenthal (1964) conducted interviews on interdepartmental relations which indicated that managers adopt values incompatible with their interdepartmental responsibilities. Walton \& Dutton (1969) conducted case studies of two manufacturing plants in conflict with one another. They found that in the plant where employees were less successful in integrating the goals of the enterprise as a whole, frustration and anxiety characterized interdepartmental relationships. Walton, Dutton \& Cafferty (1969) conducted a major study of interdepartmental conflict in which the subjects were more than 300 managers with substantial interdepartmental responsibilities. They identified various causes of interdepartmental conflict such as jurisdictional ambiguity and departmental interdependence. With the use of questionnaires and interviews, Corwin (1969) tested various propositions relating to organizational and interdepartmental conflict in public high schools. Terhune (1970) established that a basic cause of conflict between groups is incompatibility which could arise over goals, subgoals or resources. Incompatibility was more likely to develop among individuals who disliked or distrusted one another. Hamburger, Guyer \& Fox (1975) conducted research with respect to the causes of intergroup conflict in six manufacturing plants. Googe (1978) administered 60 students at Sheffield City Polytechnic with a questionnaire listing 31 possible causes of 'difficulties between groups'. Alderfer \& Smith (1982) discussed the nature of intergroup forces in organizations and conducted studies on the basis of certain propositions about groups.

\section{Interdepartmental power}

Narrower aspects of interdepartmental conflict such as power, have also been researched to a limited degree. Zald (1962) conducted research on the power-related aspect of conflict in organizations. The importance of information in gaining and maintaining power was noted by Crozier (1964). Mechanic's study (1962) pointed to the significance of access to information, 'important' people, and resources in order to gain power. Pettigrew (1973) also found that access to powerful people enabled members of one department to enforce their preferences on others. Hickson, Hinings, Lee, Schneck \& Pennings (1971) found evidence to support the view that the current needs of an enterprise give power to departments able to cater for that need.

\section{Interdepartmental communication}

Looking now at research on communication in business enterprises, interviews conducted by March \& Simon (1967) indicated that members of different departments may have trouble agreeing upon facts because of differing sources of information. Dearborn \& Simon (1958) established that even when exposed to the same sources of information, managers in different departments tend to be more concerned with differing aspects of the information. Alderfer (1977) discussed the difficulties involved in obtaining access to intergroup data in organizations, and analysed methods for data collection. Saunders (1981) set out a methodology for influencing the distribution of both power and communication be tween departments.

\section{Doctoral dissertations}

Increasing concern with the departmental scenario has resulted in the writing of several doctoral dissertations on the subject. Graeven (1970) conducted an experimental investigation of intergroup conflict and negotiations between group representatives. Thomas (1971) explored the use of five conflict-handling modes in interdepartmental relationships in a telephone company. Hunger (1973) tested the effectiveness of superordinate goals (overall goals) as a means of reducing intergroup conflict. Isgar's thesis (1975) dealt with: 'The Impact of Boundary Agreement, Level of Dependence and Direction of the Task Flow On Intergroup Conflict and Intergroup Effectiveness'. Chan (1981) examined intergroup (interdepartmental) conflict between the research and development (R\&D) managers and $R \& D$ nonmanagers of technical staff in the R\&D divisions of four aerospace companies. Johnson's thesis (1981) is an investigation of the relationship between organizational identification, departmental cohesiveness and interdepartmental conflict among department members in selected public high schools in Georgia.

\section{Theoretical articles}

Apart from empirical research, some seminal theoretical articles on interdepartmental conflict were written during the sixties. These writers have generally pointed to the lack of work and research on the subject and their articles have certainly laid the groundwork for further research. Landsberger (1961) was one of the first writers to stress the importance of the horizontal dimension in organizations. Strauss wrote a seminal article (1962) in which he analysed 'tactics of lateral relationships'. Seiler's well known article in the Harvard Business Review (1963) deals with various causes of interdepartmental conflict. Walton (1966) drew attention to the joint decision processes, competitiveness, structural (organizational) variables and attitudes between departments which can lead to conflict. Walton \& Dutton (1969) wrote a similar paper highlighting fundamental causes of interdepartmental conflict such as mutual task dependence, role dissatisfaction, dependence on common resources and communication obstacles.

\section{Methodology}

Aim of the investigation

This investigation is aimed at determining the nature, causes and extent of interdepartmental conflict in large 
manufacturing enterprises in South Africa. The intention is to establish whether a number of fundamental causes of interdepartmental conflict (according to managerial literature) are in fact perceived as a source of conflict by South African managers, and if so, to what degree.

\section{The industry sector}

The investigation was limited to the manufacturing sector. Manufacturing enterprises conform more closely than any other to the concept of the enterprise used in managerial literature. Much of the existing theory on which this investigation is based, deals with enterprises containing the four essential departments of marketing, finance, production and personnel. Large manufacturing enterprises inevitably contain specialist departments which perform these functions. It should also be noted that manufacturing is the largest contributor to South Africa's gross domestic product.

\section{Stratification of the Industry sector}

\section{Stratification by size of enterprise}

The study is limited to large enterprises only. Size is a fundamental consideration with respect to interdepartmental conflict. The larger the enterprise, the more complex the departmental interaction and the greater the expected degree of difficulty in achieving effective coordination. Larger enterprises could be expected to experience a different (and probably greater overall) degree of interdepartmental conflict. For the purposes of the study, 'large' is defined as of sufficient magnitude to contain distinct and autonomous departments. To this end, only enterprises with in excess of $\mathbf{3 0 0}$ employees were included in the sample. Enterprises with fewer than 300 employees may not be clearly departmentalized. Enterprises included in the sample were divided into three groups as follows:

Size group 1 (SGl): enterprises with between 300 and 500 employees.

Size group 2 (SG2): enterprises with between 500 and 1000 employees.

Size group 3 (SG3): enterprises with more than $1000 \mathrm{em}$ ployees.

\section{Stratification by geographic location}

The sample extends throughout South Africa, there being no logical reason to limit a postal survey to one particular region. In fact, the investigation should be of greater general applicability if undertaken on a national level. It is, however, conceivable that the geographic location of an enterprise would exert an impact on the degree of interdepartmental conflict experienced within it. Such factors as the work ethic or the state of labour relations could be different between regions. For example, the heavily industrialized Transvaal-Johannesburg region might be characterized by tremendous pressures to generate high levels of production, whereas such an ethic may be less pronounced in the Cape. Similarly, geographical differences in the composition of the labour force might affect interdepartmental conflict. For these reasons, it was decided to test statistically for differences in interdepartmental conflict between geographic regions. Within the size-group stratification, each enterprise was allocated to one of the following geographic regions:

Cape

Natal

Transvaal

Orange Free State

Independent States

The first three make up by far the majority of the sample as the last two areas do not have a developed manufacturing base.

\section{The construction of the questionnaire}

The questionnaire contained 24 multiple choice questions, each formulated in terms of five-point Likert scales. The questionnaire was limited to this number of questions so that it would solicit sufficient feedback to evaluate interdepartmental conflict in reasonable detail, without being too onerous to the respondent. An excessively long questionnaire would lower the response rate and/or reduce the care taken over answering the questions. All questions referred to the department of which the respondent is a member, in relation to the department with which he has the most dealings or is the most dependent upon. Thus, the related issues of dependence and frequency of contact were made the fundamental criteria for the selection of departments. The 24 questions were placed in five categories, each of which represents a fundamental cause of interdepartmental conflict, according to the literature.

These are: Interdepartmental Compatibility; Interdepartmental Communication; The Quality of the Interdepartmental Relationship; Conflictory and Nonconflictory Behaviour; and Interdepartmental Power.

Each individual item in the categories can now be described. Question 1 dealt with conflicting activities, 2 with conflicting priorities over day-to-day activities, 3 with conflict caused by differences in the type of people in the departments and 4 with the degree of cooperation rather than competition between the two departments.

Questions 5 - 8, comprising the second set, examined the efficiency and effectiveness of interdepartmental communication. Question 5 dealt with the provision of relevant interdepartmental information, 6 with jurisdictional ambiguity, 7 with the openness of communication and 8 with the availability of members of other departments.

Questions 9 -12, comprising the third set, dealt with the overall quality of the interdepartmental relationship, and specifically with how the respondent felt the other department treated his department. Question 9 referred to confidence in the other department, 10 to appreciation of the contributions of the respondent's department, 11 to consideration shown by the other department and 12 to the responsiveness of the other department to requests or proposals.

Questions $13-20$, comprising the fourth set, formed a measure of the level of conflictory and non-conflictory 
behaviour between the departments. Eight types of behaviour, four positive (desirable) and four negative (undesirable) were listed and respondents were requested to indicate how frequently each occur in the relationship between his department and the other department, irrespective of which department is responsible. This set of questions provided feedback on the observable manifestation of desirable and undesirable behaviour. It was therefore a more direct measure of manifest rather than latent conflict.

Questions 21 - 24, comprising the fifth and final set, examined interdepartmental power imbalances. Question 21 dealt with the possibility of wielding power through appealing to a higher authority. Question 22 referred to power derived by withholding support from the other department. Question 23 dealt with the frequency with which logical argument and sound reasoning form the basis of influence. The greater the use of logic, the less likely it would be that members of a department would resort to invalid means of influence. Finalty, question 24 referred to the frequency with which one department succeeds in imposing its preferences on another.

\section{Administration of the questionnalre}

Pilot Study

The pilot study was conducted by mail so as to be as close as possible to the methodology of the main study. A total of 80 questionnaires was sent out; 20 each were addressed respectively to 'The Marketing Manager', 'The Financial Manager', 'The Production Manager' and 'The Personnel Manager'. The questionnaires were also divided as evenly as possible among the size groups of enterprises. Therefore, 27 were sent to enterprises in Size Group 1, 27 to Size Group 2 and 26 to Size Group 3. All envelopes were numbered in order to keep track of which potential respondents had in fact replied. The covering letter explained the objectives and nature of the research and ensured the respondent of confidentiality and anonymity. The pilot study questionnaires were sent out on 21st October 1985. By 18th November 1985, 26 responses had been received. All respondents filled in the questionnaire satisfactorily and there were no apparent difficulties with any individual questions or the questionnaire in general. It was thus assumed that there was overall consensus on the suitability of the questionnaire in terms of length, structure and the nature and wording of the questions. No follow-up procedures were necessary as the number of responses received (26) was sufficient to validate the questionnaire statistically by means of correlation coefficients.

\section{Main study}

The main study was administered in a similar fashion but on a larger scale. Over the period 15 - 16 January 1986, a total of 900 questionnaires was dispatched, 300 to each size group. Within each 300 , the respondents were addressed as follows: 75 each to personnel, finance, marketing and production managers. No follow-up procedures were necessary as 282 usable questionnaires were received from the initial mail shot by 9 March 1986.

\section{Survey results}

\section{Breakdown of the response patterns}

Of the 282 usable questionnaires received, information on size group and geographic location was missing from 45 , which were however, quite usable in other respects. The response breakdown for size group is shown in Table 1.

Table 1 indicates that a reasonably even distribution of questionnaires was obtained in terms of the size of enterprise. Table 2 provides a breakdown of the questionnaire responses in terms of geographic location.

It is evident that the responses are heavily weighted in favour of the major industrial areas, the Transvaal, Cape and Natal. For all practical purposes, the survey can be considered as deriving from these three regions only. Few questionnaires were sent to the other regions and even fewer responses were elicited, simply because South African manufacturing is so dominantly located in the three primary locations.

It is now appropriate to move on to the information regarding the responding departments; that is, the department of which the respondent is a member and the 'other' department, the one with which he has the most dealings or is the most dependent upon. Table 3 indicates the responses to the former, the department of which the respondent is a member.

Table 3 reflects a reasonably even spread between departments of which the respondent is a member. Table 4

Table 1 Frequency of questionn aire responses for size group

\begin{tabular}{lcc}
\hline & $\begin{array}{c}\text { Absolute } \\
\text { Frequency }\end{array}$ & $\begin{array}{c}\text { Relative } \\
\text { Frequency (\%) }\end{array}$ \\
\hline $\begin{array}{l}\text { Size group 1 } \\
\text { (300-500 employees) }\end{array}$ & 71 & 25,2 \\
$\begin{array}{l}\text { Size group 2 } \\
\text { (500-1000 employees) }\end{array}$ & 83 & 29,4 \\
$\begin{array}{l}\text { Size group 3 } \\
\text { (over 1000 employees) }\end{array}$ & 83 & 29,4 \\
$\begin{array}{l}\text { Missing data } \\
\text { Total }\end{array}$ & 45 & 16,0 \\
\hline
\end{tabular}

Table 2 Frequency of questionn aire responses for geographic location

\begin{tabular}{lcc}
\hline Geographic location & $\begin{array}{c}\text { Absolute } \\
\text { Frequency }\end{array}$ & $\begin{array}{c}\text { Relative } \\
\text { Frequency }\end{array}$ \\
\hline Cape & 70 & 24,8 \\
Natal & 56 & 19,9 \\
Transvaal & 107 & 37,9 \\
Orange Free State & 3 & 1,1 \\
Homelands & 1 & 0,4 \\
Missing & 45 & 16,0 \\
Total & 282 & 100,0 \\
\hline
\end{tabular}


Table 3 Response breakdown of 'own department'

\begin{tabular}{lcc}
\hline & $\begin{array}{c}\text { Absolute } \\
\text { Frequency }\end{array}$ & $\begin{array}{c}\text { Relative } \\
\text { Frequency (\%) }\end{array}$ \\
\hline Production & 88 & 31,2 \\
Marketing & 52 & 18,4 \\
Finance & 67 & 23,8 \\
Personnel & 75 & 26,6 \\
Total & 28 & 100,0 \\
\hline
\end{tabular}

Table 4 Response breakdown of 'other department'

\begin{tabular}{lcc}
\hline & $\begin{array}{c}\text { Absolute } \\
\text { frequency }\end{array}$ & $\begin{array}{c}\text { Relative } \\
\text { frequency (\%) }\end{array}$ \\
\hline Production & 166 & 58,9 \\
Marketing & 71 & 25,2 \\
Finance & 32 & 11,3 \\
Personnel & 13 & 4,6 \\
Total & 282 & 100,0 \\
\hline
\end{tabular}

indicates the responses to the item as to the department with which the respondent has the most dealings or is the most dependent upon. (Responses from such departments as transport and catering, which do not fit into the above categorization, were discarded.) The dominance of production, followed by marketing is unmistakable.

Reliability

All statistical data are computed by means of the Statistical Package for the Social Sciences (SPSS) (Nie, Hull, Jenkins, Steinbrenner \& Brent, 1981). The internal reliability or consistency of the questionnaire was tested through the use of the RELIABILITY subprogramme of SPSS. All Alpha coefficients with the exception of that for Question 21 would have yielded a higher Alpha if excluded. This item was excluded from the factor analysis and analysis of variance. However, the item is in itself not unsatisfactory and was therefore included in the descriptive statistics such as means and frequency distributions. The standardized item Alpha is 0,85 which is high. The conclusion drawn is that the questionnaire meets the criterion of internal consistency.

\section{Factor Analysis}

The Eigen values of the variables suggest a onedimensional research instrument. An oblique rotation was conducted, which the nature of correlations for this investigation suggest is sufficient. The rotation again concurs with the one-dimensionality suggested by the Eigen values.

Analysis of variance

Firstly, one-way ANOVA was performed with respect to the independent variable 'own department', the department of which the respondent is a member, and the dependent variable of interdepartmental conflict. The objective was to determine whether or not there is any statistically significant difference between the responses from different groups of managers. For example, is there a statistically different degree of conflict between the responses of marketing and production managers? This test revealed an $F$ value of 0,456 and a probability of $F$ under the null hypothesis of 0,7133 . With a significance level or Alpha of 0,5 no statistically significant difference was revealed between the responding departments.

A second one-way ANOVA was performed with respect to both 'own department' and 'other department'. Again, the results imply that the null hypothesis should not be rejected as the probability of 0,6997 is not smaller than the Alpha value of 0,05 . Therefore, statistically, there is no difference between the means for either own or other department. Two-way ANOVA for geographic location and size group of enterprise again exhibits significance levels for size group, geographic location and the two-way interaction which are not less than the Alpha of 0,05 . Therefore, the null hypothesis is not rejected. Size of enterprise and geographic location do not show a differentiation in conflict. It is worth noting, however, that size of enterprise would have been significant if an Alpha of 0,1 had been selected.

\section{Descriptive statistics for the five sets of questions}

As explained, the 24 questions making up the questionnaire were divided into five sets on the basis that each forms a distinct element or category of causes of interdepartmental conflict. Because the questionnaire was based on ordinal scaling, ANOVA is not appropriate in this instance, but the descriptive statistics are presented in Tables 5 and 6.

The means are generally similar to one another, although those for compatibility and power are marginally higher. No statistically significant results can be inferred from these statistics. Pearson correlation coefficients were calculated for the five sets of questions. In order to fit the headings for the five sets of questions on one line, it is necessary to abbreviate the names of the sets to COMPAT (compatibility), COMM (communication), RELAT (relationship), and BEH (behaviour). POWER remains unchanged. All correlation coefficients are positive, but of varying strength.

Table 5 Means and standard deviations for the five sets of questions

\begin{tabular}{llc}
\hline Group & Mean & Standard deviation \\
\hline Compatability & 3,1092 & 0,6333 \\
Commurication & 2,6033 & 0,5952 \\
Relationship & 2,7523 & 0,6650 \\
Behaviour & 2,6513 & 0,4906 \\
Power & 2,8815 & 0,4327 \\
Total & 2,7528 & 0,4301 \\
\hline
\end{tabular}


Table 6 Correlation coefficients between the five sets of questions

\begin{tabular}{lrccccc}
\hline & COMPAT & COMM & RELAT & BEH & POWER & TOTAL \\
\hline COMPAT & 1,00 & & & & & \\
COMM & 0,40 & 1,00 & & & & \\
RELAT & 0,41 & 0,54 & 1,00 & & & \\
BEH & 0,39 & 0,56 & 0,58 & 1,00 & & \\
POWER & 0,17 & 0,35 & 0,26 & 0,48 & 1,00 & \\
TOTAL & 0,66 & 0,77 & 0,79 & 0,86 & 0,51 & 1,00 \\
\hline
\end{tabular}

Table 7 Means and standard deviations of the 24 questions (Total cases for each question = 282)

\begin{tabular}{|c|c|c|}
\hline Question & Mean & Standard deviation \\
\hline 1 & 3,06 & 1,05 \\
\hline 2 & 3,01 & 0,70 \\
\hline 3 & 3,90 & 1,02 \\
\hline 4 & 2,53 & 1,13 \\
\hline 5 & 2,54 & 0,75 \\
\hline 6 & 2,77 & 0,82 \\
\hline 7 & 2,50 & 0,97 \\
\hline 8 & 2,70 & 0,86 \\
\hline 9 & 2,92 & 0,76 \\
\hline 10 & 2,30 & 0,85 \\
\hline 11 & 2,78 & 1,02 \\
\hline 12 & 2,94 & 0,88 \\
\hline 13 & 2,52 & 0,80 \\
\hline 14 & 2,71 & 0,84 \\
\hline 15 & 2,43 & 0,82 \\
\hline 16 & 2,59 & 0,88 \\
\hline 17 & 2,41 & 0,68 \\
\hline 18 & 2,50 & 0,82 \\
\hline 19 & 3,49 & 1,02 \\
\hline 20 & 2,79 & 0,69 \\
\hline 21 & 3,30 & 0,85 \\
\hline 22 & 2,80 & 0,89 \\
\hline 23 & 2,34 & 0,67 \\
\hline 24 & 3,09 & 0,70 \\
\hline
\end{tabular}

Descriptive statistics of the 24 multiple-choice questions

The means and standard deviations for the 24 individual questions, are presented in Table 7. Each question could have exhibited a maximum possible mean of 5 due to the use of a five-point scale.It is evident that most questions revealed a moderate to high level of conflict.

\section{Analysis of results}

\section{Overall response rate}

The high response rate of $31 \%$ is probably a reflection on the perceived importance of interdepartmental conflict. In addition, the response rate suggests that the overall methodology by which the questionnaire was structured and administered was appropriate.

\section{Breakdown of responses}

First of all, there are the responses for size group as presented in Table 1 . The responses indicate clearly that the interest or concern shown towards the survey does not differ materially with respect to the size of the enterprise. This suggests that interdepartmental conflict is a matter of concern, and of more or less equal concern to all large enterprises. The responses for geographic location (Table 2) follow a pattern which is predictable in terms of the concentration of South African manufacturing industries considered.

The responses for 'own department' as reported in Table 3 have significant implications regarding the perceived relative importance of interdepartmental conflict. Production departments are the most prolific respondents, with personnel in second place. Finance falls into third place and marketing last. There is a substantial disparity between the number received from production (88) in the first place and those received from marketing (52) in the last place. These results suggest that production departments are most concerned with the issue of interdepartmental conflict. The close second position of personnel departments is not surprising. Personnel managers are those most likely to be trained in organizational theory, the nature of conflict and related disciplines. Organizational and industrial psychology and sociology are fields which could be studied by any manager. Yet, the primary application of this knowledge is in personnel management.

The responce breakdown for 'other department' (Table 4) possibly has the most significant implications of the survey. The enormous number of respondents who selected production as the other department and the very small number who chose finance or personnel as the other department are important findings. A total of 166 respondents selected production as the other department, with only 71 selecting marketing. Finance and personnel exhibited drastically lower numbers of 32 and 13. These results are unmistakable indicators of the relative importance of different departments in the departmental interaction. There is little doubt that production is the department with the most pervasive role in the manufacturing enterprise. The responses for finance and even more so for personnel, show that these are departments with which the others seldom have the most dealings or are the most dependent upon. It is not surprising that personnel fares even worse than finance in this regard. The point is frequently made in the literature 
that many personnel departments encounter considerable difficulty in achieving a human resources orientation.

\section{Analysis of variance}

The overall level of interdepartmental conflict (measured by the entire questionnaire) experienced by members of marketing, finance, production and marketing departments does not differ significantly in statistical terms. One might have expected differences here, because each department performs quite distinct activities and has in reality a unique relationship with other departments. For example, personnel does not fit into the departmental structure in the same way as production. Every departmental interface is characterized by certain difficulties in integration with other departments. However, it may well be that the nature of the difficulties does not differ with respect to the different departments. It must be borne in mind that the questionnaire is a general one, relating to sources of interdepartmental conflict which could apply at any and all interfaces. The statistical results therefore mean that similar sources of difficulty were found to be important by members of all four types of department. The conclusion can be drawn that general nature of the cause of conflict overrides the specific nature of the interface.

The one-way ANOVA for 'own department' and 'other department' also indicates no statistically significant difference. The same sort of logic discussed above with respect to 'own department', applies once more. Although each department does possess distinctive characteristics, it appears that the overriding criterion is the general and common nature of the causes of interdepartmental conflict. These common causes seem to be more relevant than the specific departmental interface in question.

The theory of conflict suggests that a greater degree of conflict can be expected in larger, rather than smaller enterprises. However, the two-way ANOVA shows that there are no statistically significant differences between the conflict means for Size Groups 1 - 3 at an Alpha of 0,05 . This tends to confirm the breakdown of response frequency for size group presented in Table 1 which indicates a fairly even spread of responses between the three size groups. A possible explanation for the lack of a statistical difference is that all enterprises in the investigation are large (by South African standards) and that the conflict differences between large and very large enterprises are not great. A survey for much smaller enterprises might reveal statistically different levels of conflict, but the results would not be strictly comparable if the nature and extent of departmentalization differs substantially from that in larger enterprises. The two-way ANOVA for geographic location also reveals no statistically significant difference between the various regions in which the responding enterprises are situated. Evidently, environmental and other geographic disparities are not sufficiently strong to override the nature of interdepartmental relationships inside the enterprise.

\section{Statistics for the five categories of questions}

Differences between the means presented in Table 5 are not substantial, so that it is inadvisable to draw conclusions from their ranking. The correlations between each set of questions and the totals presented in Table 6 and the totals, are high. This suggests that each set fits in well with the overall theme of the study, and supports the one-dimentionality indicated by the factor analysis. The only low correlation in this respect is for POWER, again as a result of Question 21 which does not tie in with the other factors particularly well. Because of this same factor, the POWER columns show generally lower correlations than do the others. The remaining correlations generally range between 0,4 and 0,6 , suggesting a reasonably strong positive relationship with each other. In each instance this means that where conflict is manifested on one set of questions, it can reasonably be expected to a more or less corresponding degree on the other set. For example, a high conflict measure on COMPAT is associated with a similarly high score for COMM. Also, the higher the score for the one set, the higher the score for the other. The positive association suggests that where interdepartmental conflict prevails, it is caused by a more or less consistent and uniform set of causes.

Conflict levels exhibited by the 24 multiple-choice questions

A detailed analysis of the results of each individual question would be prohibitively long. Suffice it to say that all questionnaire items do reveal a fair to large degree of conflict. Table 8 is a summary of the descriptive results for all 24 questions. Each question is placed in one of three categories - high, moderate and low conflict, based on the mean responses and the distribution of responses in terms of the wording of each question and its response scale. Because of the degree of central tendency (few responses were given on either extreme end of the scale), each item can be categorized in this fashion. The number of the question, the issue with which it deals, and the response in terms of the level of conflict are provided. The 'issue' is a summary in a few words of the aspect of interdepartmental conflict tested by each question.

\section{Implications for future research}

Although the investigation proved satisfactory in general, there are a number of additional ways in which the subject of interdepartmental conflict could be researched in order to build on the information obtained from this study. Firstly, while retaining the use of a questionnaire, further aspects of interdepartmental conflict could be examined. For example, a questionnaire could be developed to investigate such issues as role conflicts, departmental cohesiveness, or a specific interface such as conflict between production and marketing departments. Secondly, other branches of industry such as construction or service industries might be examined. Thirdly, the questionnaire format could be modified so as to make use of other attitude-testing techniques such 
Table 8 Level of conflict for the 24 multiple-choice questions

\begin{tabular}{rlc}
\hline Question & \multicolumn{1}{c}{ Issue } & Conflict level \\
\hline 1 & Conflicting activities & Moderate \\
2 & Conflicting priorities & High \\
3 & Differing types of people & High \\
4 & Competition over resources & Low \\
5 & Information about other department & Low \\
6 & Jurisdictional ambiguity & Moderate \\
7 & Openness of communication & Low \\
8 & Ability to contact other department & Moderate \\
9 & Confidence in other department & Moderate \\
10 & Appreciation of own contribution & Low \\
11 & Consideration for your department & Moderate \\
12 & Responsiveness of other department & Low \\
13 & Failing to reach decision & Moderate \\
14 & Arguing in emotional, irrational way & High \\
15 & Chatting informally & Low \\
16 & Distorting information & Moderate \\
17 & Solving a problem smoothly & Moderate \\
18 & Not retuming phone calls & Low \\
19 & Socializing & High \\
20 & Compromising to solve disagreement & Low \\
21 & Appealing to higher authority & High \\
22 & Withholding support & Moderate \\
23 & Logical argument & Low \\
24 & Imposing preferences & High \\
\hline & &
\end{tabular}

as semantic differential or open questions. Fourthly, a totally different research methodology such as a case study or participant observation might be used. There is considerable potential for research along these lines.

\section{Conclusions}

The responses to the questionnaire indicate that there is a considerable degree of interdepartmental conflict in large enterprises in South Africa. The responses for size group and geographic location do not show statistically significant differences, but the breakdown for 'own department' and 'other department' indicates an unmistakable dominance of the production department and secondly, the marketing department in the interdepartmental scenario. Personnel and to a lesser extent, finance departments, appear to be forced into a secondary role. The factor analysis and correlation coefficients between the individual questions and the sets of questions suggest that the questionnaire tests a homogeneous variable of interdepartmental conflict and that where present, it tends to be so in all aspects.

From a methodological point of view, the response rate, interest shown in the survey, and the statistical results confirm the appropriate nature of the survey. A national-level, mail survey using five-point scale multiple-choice questions does appear to be a valid means of measuring interdepartmental conflict. There was virtually no negative feedback on the nature of the questionnaire or the way in which it was administered either in the pilot stage or the main study.

The survey appears to have identified important causes of interdepartmental conflict with respect to be haviour, attitudes and organizational constraints and imperatives. Additional research in this field should prove fruitful.

\section{References}

Alderfer, C.P. 1977. Improving Organizational Communication Through Long Term Intergroup Intervention. J. Appl. Behav. Sci. vol.13, 193-210.

Alderfer, C.P. \& Smith, K.K. 1982. Studying Intergroup Relations Embedded in Organizations. Admin. Sci. Quart., vol.27, 35-65.

Blake, R. \& Mouton, J. 1961. Reactions to Intergroup Competition Under Win/Lose Conditions. Manage. Sci., vol.7, 420-435.

Bloch, B.J.1985. Interdepartmental Conflict - The Neglected Dimension of Management. S. Afr. J. Bus. Mgmnt., vol.16, 195-199.

Brown, L.D.1982. Managing Conflict at Organizational Interfaces. Reading, Massachusetts: Addison Wesley.

Chan, M. 1981. Intergroup Conflict and Conflict Management in the R\&D Divisions of Four Aerospace Companies. Unpublished Phd Dissertation. University of California Los Angeles.

Corwin, R.G. 1969. Patterns of Organizational Conflict. Admin. Sci. Quart., vol. 14, 507-520.

Crozier, M. 1964. The Bureaucratic Phenomenon. Chicago: University of Chicago Press.

Dearborn, D.C. \& Simon, H.A. 1958. Selective Perception: A note on the Departmental Identification of Executives. Sociometry, vol.21, 140-144.

Googe, P. 1978. Intergroup Conflict: A Rethink. Human Relations, vol.31, 475-487.

Graeven, D.B. 1970. Intergroup Conflict and the Group Representative: The Effects of Power and the Legitimacy of Power Relations on Negotiation in an Experimental Setting. Unpublished PhD Dissertation, University of Iowa.

Hamburger, H., Guyer, M. \& Fox, J. 1975. Group Size and Cooperation. J. Conflict Resolution, vol. 19, 503-522.

Hikson. D.G., Hinings, C.R., Lee, C. A., Schneck, R.E. \& Pennings, J.M. 1971. A Strategic Contingencies Theory of Intraorganizational Power. Admin. Sci. Quart., vol.16, 216-229.

Hunger, D.J. 1973. An Empirical Test of the Superordinate Goal as a Means of Reducing Intergroup Conflict in a Bargaining Situation. Unpublished PhD Dissertation, Ohio State University.

Isgar, T.A. 1975. The Impact of Boundary Agreement, Level of Dependence and Direction of the Task Flow on Intergroup Conflict and Intergroup Effectiveness. Unpublished PhD Dissertation, Purdue University.

Johnson, G.C. 1981. An Investigation of the Relationship Between Organizational Identification, Departmental Cohesiveness and Interdepartmental Conflict. Unpublished D Ed Dissertation, University of Georgia.

Kahn, R.L., Wolfe, R.M., Quinn, R.P., Snoek, J.D. \& Rosenthal, R.A. 1964. Organizational Stress: Studies in Role Conflict and Ambiguity. New York: Wiley. 
Landsberger, H.A. 1961. The Horizontal Dimension in a Bureaucracy. Admin. Sci. Quart., vol.6, 298-333.

March, J.G. \& Simon, H.A. 1967. Organizations. New York: Wiley, 1967.

Mechanic, D. 1962. Sources of Pow'er of Lower Participants in Complex Organizations. Admin. Sci. Quart., vol.7, 349-364.

Nie, N.H., Hull, C.H. , Jenkins, J.G., Steinbrenner, K. \& Brent, D.H. 1981. Statistical Package for the Social Sciences. New York: McGraw-Hill.

Pettigrew, A. 1973. The Politics of Organizational Decision Making. London: Tavistock.

Pondy, L.R. 1964. Budgeting and Intergroup Conflict in Organizations. In: Leavitt, H.J. \& Pondy, L.R. Readings in Managerial Psychology. Chicago: University of Chicago Press.

Saunders, C.S. 1981. Management Information Systems, Communications and Departmental Power: An Integrative Model. Academy Manage. Rev., vol.6, 431-442.

Seiler, J.A. 1963. Diagnosing Interdepartmental Conflict. Harv. Bus. Rev., vol.41, 121-132.
Strauss, G. 1962. Tactics of Lateral Relationhips. Admin. Sci. Quart., vol.7, 291-298.

Terhune, K.W.1970. The Effect of Personality in Cooperation and Conflict. In: Swingle, P. (ed.) The Structure of Conflict. New York: Academic Press.

Thomas, K. W. 1071. Conflict Handling Modes in Interdepartmental Relations. Unpublished PhD Dissertation, Purdue University.

Walton, R.E. 1966. Theory of Conflict in Lateral Organizational Relationships. In: Lawrence, J.R. (ed.) Operational Research and the Social Sciences. London: Tavistock.

Walton, R.E. \& Dutton, J.M. 1969. The Management of Interdepartmental Conflict: A Model and Review. Admin. Sci. Quart., vol.14, 73-84.

Walton, R.E., Dutton, J.M. \& Cafferty, T.P. 1969. Organizational Context and Interdepartmental Conflict. Admin. Sci. Quart., vol.14, 522-542.

Zald, M.W. 1962. Power Balance and Staff Conflict in Correctional Institutions. Admin. Sci. Quart., vol.7, 22-49. 